Covered in: ERIH PLUS, HeinOnline, CEEOL, Index Copernicus, CrossRef, CrossCheck, J-GATE, Google Scholar, Ideas RePeC, Econpapers, Socionet, KVK, WorldCat.

2018, Volume 6, Issue 2, pages: 01-13 | doi: https://doi.org/10.18662/lumenlaw/08

\section{New Developments of the International Law, at the Beginning of XXIst Century: Towards a Global Charter of Nations Rights}

\section{Mădălina Virginia ANTONESCU1}

${ }^{1}$ Ph.D., scientific collaborator, Academia Oamenilor de Stiinta din Romania, vam55ro@yahoo.com

\begin{abstract}
At the beginning of the $21^{\text {st }}$ century, international law remains in its essence an inter-state law, which does not recognise nations as distinct subjects of law (with the exception of peoples fighting for their independence). In the present paper, we propose a study devoted to the idea that, in the future, in the context of fundamental shifts of the global world, therefore, in the context of inevitable developments in international law, peoples (nations) will become distinct subjects of law, in comparison to states, as holders of rights and obligations that are specific to the new global law, as we will try to explain. Starting from the consecration of the third generation of human rights as rights of solidarity, surpassing the strictly individual field of legal protection, new categories of fundamental rights for the peoples can be developed, recognised as such by the states and international organisations, on the basis of sustainable development and of the "no one will be left behind "principles, that are defined inclusively in the 2030 Agenda.
\end{abstract}

Keywords: states, global law, peoples, collective rights of peoples, solidarity rights, global normative regimes.

How to cite: Antonescu, M. (2018). New Developments of the International Law, at the Beginning of XXIst Century: Towards a Global Charter of Nations Rights. Logos Universality Mentality Education Novelty: Law, 6(2), 01-13. https://doi.org/10.18662/lumenlaw/08 


\section{Current Legal Stage: Non-acknowledgement of the "Nation- People" as a Distinct Subject of International Law}

According to the current international law, which is an inter-state law (acknowledging only the states as original, principal and sovereign subjects of law (Diaconu, 2002, p. 397), not the peoples as well), besides the states there is a distinct legal, special category of subjects of international law: the peoples (or nations) fighting for independence. The doctrine also calls them movements of national liberation, independence movements or belligerent communities (Diaconu, 2002, pp. 474-475). Thus, in the contemporary international law, the people as such is not acknowledged as a distinct subject of international law, only the people fighting for independence receives such an acknowledgement (the people yet to be organized in a state and that is engaged in a battle for independence from a colonial, foreign domination or from domination exercised by a foreign power). As a result, the representatives of these peoples newly organized as states, engaged in a fight for independence, are legally acknowledged at international level, receiving diplomatic immunity, as well as other legal rights. Moreover, the UN Charter specifies the principle of peoples' rights to determine themselves (or the right to selfdetermination), which has led to the peoples fighting for independence (Diaconu, 2002 , p. 475) being granted an international legal status, as the doctrine noted.

In addition, the Declaration on the principles of international law, regarding the amicable relations and cooperation among the states, adopted by UN GA Resolution 2625/XXV dated 1970, expressly refers to the principle of equality of rights and self-determination of peoples. The Declaration also stipulates that all the peoples have the right to freely determine their own political status, without involvement from the outside, and it imposes for the states signing it the legal obligation of "refraining from any action of force, which deprives the mentioned states from their right to self-determination, freedom and independence".

The Declaration on the Granting of Independence to Colonial Countries and Peoples, adopted by the UN GA Resolution 1514/XIV dated December $14^{\text {th }} 1960$ banned the use of force by the colonial powers, against the colonial peoples, for "the colonial peoples to exercise their right to complete freedom peacefully and freely, while the integrity of their territory is observed".

As a result, in the numerous resolutions regarding the peoples, the UN GA refers to the peoples under foreign occupation, under colonial domination, as a type of peoples with a specific legal status, noncompliant 
with the principles of sovereignty and equality of rights of the states, in the UN Charter. These peoples or movements of national liberation are subject to the right to self-determination, they have a special status, acknowledged by the contemporary international law and they refers to communities yet to be structured as sovereign, independent states.

The right of the peoples to national liberation is different from the secession cases, in which the territorial integrity or political unity of a state is affected, as well as from the cases of civil war and the cases of claims of territorial autonomy made by national minorities ((Diaconu, 2002, p. 480) (collective rights such as the rights of national minorities are not acknowledged internationally, unlike the individual rights, belonging to the people who are part of national minorities - such rights are human rights and they are not related to the right to self-determination, acknowledged only for the peoples).

Thus, from the perspective of the current international law, the legal quality of distinct "subject of international law" only belongs to the peoples fighting for independence, not for the peoples, in general. Only their action for national liberation and the quality of people (not national minority) lead to the acknowledgement of the respective community, in the abovementioned sense. We must also note that their legal quality of subjects of international law is only temporary since, with the formation of the new state (objective of the fight for national liberation), the movement of national liberation ends (Diaconu, 2002, p. 486).

According to the current international law, the nation-states are the states with the quality of principal and sovereign subjects of law (Geamănu, 1981, pp. 276278), not the peoples as such. As a consequence, the peoples as such cannot send their own representatives to the works of international organizations; they are not properly represented in international courts of law; they cannot establish relations with other subjects of international law; they cannot sign treaties with subjects of international law (Diaconu, 2002).

However, we must add that there are no legal norms to expressly and restrictively determine the subjects of international law, this legal category being a result of the doctrine, jurisprudence, international practice (Diaconu, 2002).

According to Kelsen and the Pure Theory of Law, "any entity or person who is the direct recipient of an international law regulation" is considered subject of international law (Diaconu, 2002). From this perspective, with the transformation of contemporary international law into a global law, the nations (or peoples as such) become subjects of global law, as soon as they are direct recipients of the legal regulations of global law (the same principle applies to 
transnational corporations, which also become subjects of global law, in the $21^{\text {st }}$ century global order, once they are the direct recipients of the global law regulations).

According to another part of the international law doctrine "any person in one of the following situations: holder of international al rights, which he/she can claim at international level, or holder of an international obligation, with the capacity of committing an international crime" is a subject of international law. Using the perspective of Eustathiades and Wengler (Diaconu, 2002, p. 395) attorneys and adjusting it to the new global law, in full process of formation, at the beginning of the $21^{\text {st }}$ century, the elaboration of a legal definition of the global crime, the determination of global regulations which result in global obligations and rights, as express legal responsibility of certain subjects of global law (such as non-state actors, in our opinion, i.e. mainly peoples as such, corporations, global organizations - the ones having exceeded the stage of multilateralism and with actual global tasks, which no longer need permission or implementation from the states - therefore, with supra-states attributions) are recommendable. If we admit that peoples as such can assume global legal rights and obligations, in the global legal order of the $21^{\text {st }}$ century (distinct from the current international law, which focuses on the preeminence of the states), then their legal quality (of the peoples as such) of being subjects of global law becomes evident.

At least until the moment when the new global legal order is consolidated, the idea of two legal orders coexisting (the order of international law, dominated by states, and the order of global law, in process of formation, dominated by non-state actors) is acceptable on the premise of the states becoming weaker or declining, under the impact of the non-state actors and of the markets (Held, McGrew, Golblatt, Perraton, 2005, pp. 81-82, 109-110, 489-492).

\section{Collective Rights in the Global Order: from the Representatives of Nation-States, to the Representatives of People, in the $21^{\text {st }}$ Century Global Order}

The doctrine points out that the field of human rights includes a third generation of human rights, called collective rights or solidarity rights (Diaconu, 1995, pp. 198-199). According to the doctrine, this category includes not only the states (according to the current international law, as an inter-state law), but also the entire international community (Miga-Beşteliu, 1995). The legal object of these rights regards the very existence and functioning of the overall human community, as these rights are the following: the right to peace and security, the right to a natural and social healthy environment, the right to 
development. As noted by the doctrine, the existence of this category of rights is challenged especially by authors and states from the area of developed countries (Diaconu, 1995, p. 200). Although these rights are still insufficiently elaborated from the legal viewpoint, in the doctrine, it does not mean that they do not exist and the states have the obligation to continue their cooperation in terms of implementing and observing these rights, in their internal legal orders (Diaconu, 1995, p. 200).

Taking in account this context, we can consider that, at the beginning of the $21^{\text {st }}$ century, with the creation and consolidation of the global legal order (in the process of transfer from the Westphalian world to the global world (Held, McGrew, Golblatt, Perraton, 2004, pp. 73-83) dominated by the non-state actors, therefore a world where it is also necessary to regulate as such the activity of non-state actors, subject to a Global Charter of Nations and Corporations, as main non-state actors, which will act in the global world of the $21^{\text {st }}$ century), the solidarity rights, in their current format (as inter-state rights, which also pertain to an extended dimension of the field of human rights) can represents a premise for the legal development of the new rights and principles regarding the non-state actors (here, the post-Westphalian nations, i.e. the nations born from the concept of state, operating on their own behalf in the global order, and transnational corporations).

In the $21^{\text {st }}$ century global order, it is very important to build solid legal grounds regarding the global responsibility of the transnational corporations, for their decisions and activities with transnational or global impact; in addition, it is necessary to stipulate the global legal rights and obligations of the Corporations, in a Global Charter, while another Global Charter must stipulate a special set of global rights and obligations of the Nations, as non-state actors, acting in a world different from the Westphalian world, the world of international law.

In our opinion, the current sets of legal rights and obligations assumed by the states, in the contemporary international law, are not applicable to the global legal order, which coexists (for the time being) with the contemporary international law, which is an order in process of formation (in certain dimensions and regulatory structures) as well as consolidation (in other dimensions and regulatory structures). While the international legal order is dominated by the nation-states, the global legal order is dominated by the non-state actors (corporations, global media tycoons, transnational cults and churches, transnational NGOs etc.) (Held, McGrew, Golblatt, Perraton, 2004, pp. 79-85). In the global legal order, in relation to the global decisions and activities of the non-state actors, the states can no longer act from a level of legal superiority, they can no longer control and own phenomena specific to the global order (financial, economic, political and, finally, with legal impact). In the global 
order, the states are regarded as weakened, declining entities, incapable of elaborating legally binding regulations for the non-state actors, with formal sovereignty or forms of sovereignty diminished as compared to other historic periods. Therefore, as we see it, the states can no longer join the $21^{\text {st }}$ century global legal order (which will eventually replace the contemporary inter-state legal order) directly (as nationstates).

As an order of non-state actors (or supra-state, multi-state actors), the global order is clearly a post-Westphalian order, in which the nature of non-state actor can guarantee the success of infiltration and activation, even of controlling this type of order (political, legal, economic, cultural, in particular). Therefore, in order to find an efficient form of fighting against corporations (which have weakened the sovereign powers of the states, imposing the rule of the free market), nations will infiltrate directly in the global order, as non-state actors, i.e. they will affirm as distinct legal subjects (as compared to the states), in the global legal order. If the states continue to be the classic actors of the inter-state law (still in force, for the beginning of the $21^{\text {st }}$ century), nations (or peoples) will become the main non-state actors, directly involved on their own behalf in the global legal order, in order to counterbalance the ascending, unregulated, uncontrolled power of the corporations.

Concerning the rights of the corporations (born from the universal principle of free market, free commerce at global level, which turned them in the main actors of the global order in process of formation), a set of special rights of the nations (or peoples) will be defined (through global institutions such as deeply reformed UN - in order to be able to act and mediate the global order, completely different from today's inter-state legal order).

The representatives of the peoples will be different from the representatives of the state system (sent to act in the current inter-state law). A specific diplomacy of the nations (peoples) will be developed, especially for the global political order (dominated by non-state actors), with representatives and missions specific to the direct interest of the nations, as subjects of global law, in the global world (not in the classic world, a world of inter-state politics, of cooperation among the states).

In this context, Peoples' Houses of Diplomacy will appear and they will develop types of diplomacy distinct from the state diplomacy, able on their own to authentically engage the nations in the global legal, political and economic order.

Therefore, it is necessary to start as soon as possible the identification of fields and dimensions, of issues of global and transnational interest, in which the processes of creating global normative regimes began, to see the global proto-institutions of the $21^{\text {st }}$ century, where the non-state actors become visible through activities and decisions with global and transnational impact. Through 
this content identification in the global order, the limits of the current interstate law and of the Westphalian world, in which the main and sovereign actors continue to be the states, are clearly delimited.

Unlike the Westphalian world, whose main vulnerability is that it has lost control over the non-state actors, with actions and decisions of global or transnational impact, weakening the states, global order is an order of strict and clear legal and economic responsibility of the non-state actors, such as transnational corporations, irrespective of their field of operation.

Thus, we consider that the current legal basis, that of collective rights (or solidarity rights), which concerns the states at the present moment, can be used as a source of inspiration for the $21^{\text {st }}$ century development of new sets of solidarity rights; however, this time, these rights are direct rights of the peoples, engaged on their own behalf, as subjects of global law, in the global (post-Westphalian) order.

These fundamental rights of the peoples, at the level of the $21^{\text {st }}$ century global society, will be acknowledged as such and observed by the states, by the global institutions, as well as by the non-state actors (other nations, corporations etc.), based on a Global Charter of the Rights of Peoples, binding erga omnes in the global legal order.

\section{The Rights of the People - the People as Global Subject of Global Law in the Global Legal Order of the 21st Century. From the Peoples Fighting for Independence, to the People as a Distinct Subject of Global Law, in the 21st Century}

By transforming the public international law (inter-state, specific to the Westphalian world, a world in competition with the global order) into a global law, there are also new types of subjects of global law: non-state actors, whose transnational or even global decisions and actions have a direct, major impact on the $21^{\text {st }}$ century global order and, as a consequence, on the global law; secondly, due to the tendency of globalization (Held, McGrew, Golblatt, Perraton, 2004, pp. 39-41), as well as decline of the nation-states, in the future, we will witness the nations breaking away from the Westphalian concept of state, which reached its peak in the $20^{\text {th }}$ century; with the weakening of the states, with their withdrawal from an increasing number of decision-making areas, with the expansion of the global markets, the nations will have to react to this reality and directly assume legal rights and obligations in the new global order, in order to secure a real legal defence, at the level of the new global law (resulted from the entire consolidating web of global regimes, in certain areas of global interest). 
New Developments of the International Law, at the Beginning of XXIst ...

If the assume the position of weak actors, in this global order, which they cannot control (in which they can no longer be sovereign masters and in which they can only act through increasingly formalized and irrelevant forms of multilateral cooperation, in relation to the non-state actors), the nations will be in the position of rethinking their legal status and become their own actors, in the new global game. The nations will become the first subjects directly interested in taking control over the global order, which has escaped the control of the states and, as a consequence, to receive legal recognition distinct from the states, in the new global law (a law which the states are not interested in acknowledging and in which they are not able to play a major, effective role, as a consequence).

While the states remain captive in the old international law, continuing to engage in irrelevant, inefficient forms of multilateral cooperation, the nations which intend to play in the global order and to participate in and even to control the new global law, about to be born, send their own representatives in the forms of global cooperation, to support their interest and to contribute actively in the creation of a specific legal framework by initiating global institutions, regimes of global protection of the nations' rights, in the global order and in relation to the non-state actors, event by initiating global regulations. Having and expressly assuming the legal quality of subjects of global law (through a Charter of Rights for the Peoples in the Global Legal Order), the nations (or peoples, as such) position themselves in a legal situation superior to the current one (of the international law, which only acknowledges the states as original, principal and sovereign subjects of law). They position themselves in the global dimension, that of institutions actually having global attributions, regarding the management of global issues, of the emerging global regulatory regimes, of the global principles and objectives, which must be assumed either together with non-state actors (common, universal responsibility for the management of the common heritage of mankind, by the nations of the world and by the transnational corporations, for example), or against the non-state actors (with the peoples of the world forming new global institutions, distinct from the current institutions, with attributions regarding the monitoring and penalization of non-state actors, such as the corporations, in a series of very concrete aspects, of global interest).

Thus, in the global legal order (which is no longer defined and controlled by the states), the peoples choose to become directly involved, as such, on their own behalf, through instruments, mechanisms, regulations and powers, through new legal qualities, distinct from their status in the current international law. It is a revolutionary leap from the current international law (based on the nation-states), to the global law (based on the non-state actors, in which the peoples become authentic competition to the corporations). The $21^{\text {st }}$ century global law is dominated, controlled by the non-stat actors. To this end, the nations 
(regarded as entities directly involved in the global legal order, leaving the states with an increasingly irrelevant legal engagement, in the field of an increasingly weakened and formalized internationallaw) become the competition for the domination over the entire global legal order, in relation with other non-state actors (the corporations).

Therefore, in the 21 st century, it is possible that we witness a battle for power (in the sense of control and power to legally regulate the entire global law, according to their vision and interests) between the nations as such and the corporations, both being construed as "non-state actors", in the sense of the 21st century global law. Thus, after one of the party wins this battle, we will also see the prevailing legal regime in the 21st century global law: it will either be a mainly corporate law (effect of it being controlled by the corporations), or a global law of the world nations (effect of the global juridical law being controlled by the nations, as such). In the second sense, we can discuss about global institutions (Assembly of the World's Nations, Global Committee for the Control of Transnational and Global Activity of Corporations, Global Forum of the Non-State Actors, which is a framework for dialogue between the corporations and nations etc.), as well as global regulatory instruments, with the aid of which they define new rights of the nations as such, in the global legal order (a Global Charter of the Rights of Peoples or Nations).

\section{Global Charter of the Rights of Peoples: Legal Content}

When proposing this Charter draft, in the present paper, we consider its nature of mandatory legal document, specific to the global legal order of the $21^{\text {st }}$ century. Technically, we are discussing a pillar-document of the new global legal order, as a post-Westphalian order, conceived as an order with global institutions and regimes, which are imposed directly to the peoples that assume them as such.

In the $21^{\text {st }}$ century global legal order, the people becomes a selfaware community, holder of rights and obligations in the global legal order, according to a global law focused on the freedom of peoples and on the equality of rights among the peoples.

Among the fundamental rights of the peoples, defined in this Global Charter of the Rights of Peoples, besides rights essential for the evolution of the human community and its prosperity in the $21^{\text {st }}$ century, inspired from the current legal body of rights of the states (the right of the peoples to existence; the right of the peoples to self-determination; the right of the people to peaceful coexistence; the right of the peoples to cultural and civilizational identity; the right of the peoples to equality and independence; 
the right of the peoples to maintain and acquire land; the right of the peoples to diplomatic relations on their own behalf; the right to respect and honour, the right of the peoples to commerce; the right of the peoples to technical, technological and scientific development and progress; the right of the peoples to participate in examining and solving global issues, from an equal standpoint; the right of the peoples to cooperate among themselves, based on the principle of mutual advantage, in order to maintain global peace and security, for the prosperity of all the nations in the world), other rights can be conceived and added:

- the right of the peoples to happiness, in the $21^{\text {st }}$ century global order;

- the right of all the peoples in the world to prosperity and to fully enjoying the civilization standards of the $21^{\text {st }}$ century society (not only developed peoples);

- the right of the peoples to enjoy a healthy, sustainable environment (right derived from the right of the peoples to durable development);

- the right of the peoples to domestic use and drinking water;

- the right of the peoples to be sheltered from hunger, the right to collective food security;

- the right of the peoples to enjoy healthy, nutritious, balanced food, to fulfil their daily need

- the right of the peoples to global immediate and unconditional global assistance, from the global institutions, in case of natural calamities, disasters, destructions caused by the war or armed conflicts to the civilian population;

- the right of the peoples to protection of their cultural and spiritual heritage;

- the right of the peoples to be sheltered from negative collective stress;

- the right of the peoples to good reputation and to a good image among the peoples and in the global order (a highly virtualized order, dominated by global media companies, by the cult of image, by the permanent TV show, broadcast globally)

- the right of the peoples to be treated with respect and nondiscrimination (also from the viewpoint of their public image, in the global virtual space, in TV shows and online). Concerning this aspect, a Charter of the Rights of the Peoples to a Good Image in the global virtual order should be elaborated, clearly specifying the rights of the peoples, the rights and obligations of the global media companies and Internet users, who are not allowed to denigrate, minimize, offend the good image of a people, in the 
global online order; also, the immediate global penalization of virtual aggressions against a people, in the psychological war of image, through the negative perceptions generated, in the global interconnected world of virtual space users, must also be stipulated).

A series of rights currently considered individual will be construed in a strongly collective sense, with the tendency to acknowledge them at regional and international level, as "solidarity rights" or as "rights of the peoples" (the right of the peoples to drinking, safe water, the right of the peoples to sheltered from hunger, the right of the peoples to a decent living, the right of the peoples to receive healthy, nutritious and balanced food). All these rights (rather recent as individual rights as well, at this point) are correlated to the right to happiness, as a collective right (acknowledged for the peoples), whence a great evolution in the entire international public law, at the beginning of the $21^{\text {st }}$ century.

In addition, we can identify in the legal content of a right of the peoples to happiness, defined in a future international legal document, a series of rights (also construed as rights of the peoples), which are not subject to the area of human rights, but directly to the global law. In the $21^{\text {st }}$ century, these rights will lead to a development of the international law, in the sense of its humanization (from a state-centred law, to a law centred on organic communities, in the global society, as a response to the challenges of globalization and to the impossibility of the states to exclusively provide solutions to the problems with trans-border or even global effects). In this context, we consider that it would be possible to draft a Global Charter of the Peoples, in the context of the global society, in which the right of the peoples to happiness is sanctioned and acknowledged by all the peoples, not only the peoples fighting for independence (in which case happiness would have a political connotation, the sense of obtaining independence and creating a state), from the very first article of the Charter.

Other rights entailed by an extended view of the right of the peoples to happiness, which would be sanctioned at the level of $21^{\text {st }}$ century global legal order, are the following:

- the right of all the peoples to peace and stability of the international political environment;

- the right of all the peoples to cultural identity; standard;

- the right of all the peoples to achieve welfare and a high life

- the right of the peoples to have an active contribution in the creation, preservation and expansion of the cultural heritage of the mankind and to benefit from free access to the values of this heritage (which would require the creation of a special global legal regime, for protection in case of 
conflict or aggression from the non-state or quasi-state actors, such as various terrorist or fundamentalist organizations, in the areas of world cultural importance);

- the right of the peoples to fully benefit from the discoveries of science and technology, from green technology (with minimum effects or no harmful effects on the environment);

- the right of the peoples to enjoy a healthy, unpolluted, harmonious natural and social environment (including the urban environment);

- the right of the peoples to live in harmony and to cooperate with other peoples, for the achievement of peace and international stability (including the aspects concerning the dialogue of civilizations);

- the right of the peoples to international cooperation with mutual advantages and the right of the peoples to live in good vicinity relations.

\section{Conclusions}

In conclusion, we can say that we are witnessing a transition from the Westphalian world, affected by its main vulnerability (incapacity of the states to control non-state actors and hold them responsible, non-state actors such as corporations, media companies in particular), towards the global order (legal, economic and cultural). This does not mean that we are talking about an imminent disappearance of the Westphalian world; instead, we are talking about a coexistence stage (at least for the beginning of the $21^{\text {st }}$ century), each world baving its own actors and rules of functioning.

However, the states will no longer be the main actors of the global order (including the legal order) of the $21^{\text {st }}$ century and it will be necessary that the nations (or peoples) act directly, through involvement (legal, as well, since they become subjects of global law) in the global order, to prevent it from being controlled by corporations and global media companies. In this context, the creation of a Global Charter of Rights of the Peoples becomes a necessity, a document in which the peoples define a set of rights which become binding erga omnes, in the $21^{\text {st }}$ century global order (thus, avoiding the risk of this order becoming chaotic or regulated by principles specific to corporations and global media companies - the principle of rating and the principle of free market, completely unfavourable for the rights and prosperity interests of the nations).

Beyond the academic debate on the involvement or lack of involvement on their behalf of the peoples in the global order, the clash between the world of peoples, states and the world of non-state actors operating at global level will trigger a clear need for protection of the peoples, in a post-Westphalian world. 
It is clear that this protection is not possible in the context of a legal apathy or absence of the peoples in the new global order.

Therefore, it will be necessary that the peoples be actively involved, on their own behalf, at global level, through their representatives (non-state, since the state representatives of the peoples act in the classic and decadent inter-state order, through the classic forms of diplomacy). We are talking about the occurrence of a global diplomacy of nations, a diplomacy that considers nations to be subjects of global law, with their own legal personality in the global law, a postWestphalian diplomacy able to support the direct interest of the nations, as compared to the non-state actors, such as corporations and global media companies, where the states have failed.

\section{Acknowledgment}

This paper was presented at the 15th Anniversary Edition World Congress LUMEN, Iasi, Romania, April 12-17, 2016. The present article represents only the personal opinion of the author and it does not involve in any form any other natural person or legal entity. All the rights over the present text are reserved. The quotations from the present text are made by mentioning the author and the complete source.

\section{References}

Diaconu, I. (1993). Drepturile omului, Romanian Institute for Human Rights, Bucharest, pp. 43-47.

Diaconu, I. (2002). Tratat de drept internaţional public, vol. I. Bucharest: Lumina Lex Publishing House.

Geamănu, G. (1981). Drept international public, vol. I. Bucharest: Ed. Didactică şi Pedagogică.

Held, D., McGrew, A., Golblatt, D., Perraton, J. (2004). Transformări globale. Politică, economie şi cultură, translated by Ramona-Elena Lupaşcu, Adriana Ştraub, Mihaela Bordea, Alina-Maria Turcu. Iaşi: Polirom. pp. 81-82, 109-110, 489492.

Miga-Beşteliu, R. (1995). Drept internațional. Introducere în dreptul internațional public, All-B Publishing House, Bucharest.

Puşcaş, V. (2005). Relații internaționale/ transnaționale. Cluj Napoca: Sincron Publishing House. 